\title{
Psychopathic Leadership A Case Study of a Corporate Psychopath CEO
}

\author{
Clive R. Boddy ${ }^{1}$
}

Received: 8 September 2014 / Accepted: 12 October 2015/Published online: 19 October 2015

(C) The Author(s) 2015. This article is published with open access at Springerlink.com

\begin{abstract}
This longitudinal case study reports on a charity in the UK which gained a new CEO who was reported by two middle managers who worked in the charity, to embody (respectively) all or most of the ten characteristics within a measure of corporate psychopathy. The leadership of this CEO with a high corporate psychopathy score was reported to be so poor that the organisation was described as being one without leadership and as a lost organisation with no direction. This paper outlines the resultant characteristics of the ensuing aimlessness and lack of drive of the organisation involved. Comparisons are made to a previous CEO in the same organisation, who was reportedly an authentic, effective and transformational leader. Outcomes under the CEO with a high corporate psychopathy score were related to bullying, staff withdrawal and turnover as effective employees stayed away from and/or left the organisation. Outcomes also included a marked organisational decline in terms of revenue, employee commitment, creativity and organisational innovativeness. The paper makes a contribution to both leadership and to corporate psychopathy research as it appears to be the first reported study of a CEO with a high corporate psychopathy score.
\end{abstract}

Keywords Corporate psychopaths - Leadership . Transformational leadership · Employee voice . Leaderless-ness

Clive R. Boddy

crpboddy@gmail.com; c.boddy@mdx.ac.uk

1 Middlesex University Business School, Room W133, Williams Building, The Burroughs, Hendon, London NW4 4BT, UK

\section{Introduction}

That personality traits have an effect on employee behaviour including behaviour relating to risk taking, leadership and engagement is well established, and for example, studies of narcissism are fairly common in the literature, e.g. (Hochwarter and Thompson 2012; Stein 2003; de Vries 1985). However, although criminal psychopathy (Taylor 1964) has been addressed in leading management journals, corporate psychopathy is largely absent. This current paper is important because it helps address this absence of knowledge regarding corporate psychopaths (Stevens et al. 2012), whom some commentators regard as being a serious threat to the practice of business ethics (Marshall et al. 2015). The subject of corporate psychopaths as leaders is also reported to be an important new direction for leadership research (Gudmundsson and Southey 2011).

Researchers in leadership have argued for qualitative approaches which acknowledge the theory-laden, interpretative nature of empirical studies (Alvesson 1997). Alvesson suggested the use of a situational approach with careful descriptions of naturally occurring events presented in texts in ways that they are open for different interpretations from those chosen by the author. This paper adopts such a qualitative method in the form of a case study approach towards studying the effects of a corporate psychopath in a leadership position. The paper reports on what appears to be the first empirical, although essentially qualitative, study of a psychopathic CEO. Disgraced CEOs such as Lay (Enron), Maxwell (Mirror Group) and Madoff have been nominated as possible corporate psychopaths after their downfalls (BBC News 2004; Strom 2009).

However, such post hoc explanations have not been elaborated in any systematic manner. This current paper 
examines a CEO at the time of his leadership of the organisation and represents the first study to do this.

CEO personal traits have been linked to scandals in the banking sector (Zona et al. 2013) but not specifically in relation to corporate psychopaths. This current research specifically investigates psychopathic CEO behaviour and outcomes and so helps fill a gap in current knowledge regarding corporate psychopaths.

The paper first discusses the importance of leadership in order to contextualise the research and then introduces the corporate psychopath. The research method is detailed and then the findings are presented. To give voice to the interviewee, who had largely been denied a voice in the organisation concerned, and to allow the open presentation of original texts called for by Alvesson (1997), verbatim quotes are used extensively in this paper. The findings are then discussed in the light of previous explorations of the effects of having corporate psychopaths present in organisations. Conclusions regarding the leaderless-ness of the case are then drawn.

\section{Leadership}

A review of the literature on leadership, personality and organisational effectiveness makes three important points about leadership (Hogan and Kaiser 2005). Firstly, leadership is hugely consequential and arguably the single most important issue in the human sciences.

Further, leadership concerns the performance of teams, groups and organisations and promotes effective team and group performance and well-being (Hogan and Kaiser 2005). Finally, personality predicts leadership via personality's influence on leadership style which influences employee attitudes and team performance which in turn influence organisational performance (Hogan et al. 1994; Hogan and Kaiser 2005).

In terms of destructive or dark leadership, commentators have suggested that the base level for managerial incompetence is quite high (Hogan and Hogan 2001) and so an understanding of any personality-based correlates of such incompetence would arguably be welcome. In both previous quantitative and qualitative research such dark leaders have been found to make decisions with destructive long-term consequences and to exhibit ineffective leadership (Baker 2013; Kaiser et al. 2013) and this current study increases the focus of such research by concentrating particularly on a $\mathrm{CEO}$ with a high corporate psychopathy score. In recognition that people are much more than their maladies, the term "CEO with a high corporate psychopathy score" is preferable to the terms "corporate psychopath CEO" or "psychopathic CEO". However, having recognised this point, due to space considerations and for ease of reading, in the rest of this paper I will use the latter two terms to describe the $\mathrm{CEO}$ whose behaviour is under review.

Within the leadership literature, it has been asserted that methodological advancements are enabling a renaissance in individual difference research in leadership, potentially linking traits to behaviours and attitudes and then to leader outcomes (Antonakis et al. 2012).

Psychopathy involves a constellation of traits such as charm, deceit, manipulation, lying and ruthlessness that would theoretically result in selfish and toxic leadership. This research therefore attempts to make links between traits, behaviours and outcomes as suggested by Antonakis et al. (2012).

According to a recent review of the literature on destructive leadership (Aasland et al. 2010), organisational research finds that 60-75\% of all employees typically reported that the worst aspect of their job was their immediate supervisor (Hogan et al. 1990). Further, that job pressure has been cited in $75 \%$ of workers' compensation claims in which mental stressors were the main cause of absenteeism, and $94 \%$ of those claims allegedly involved abusive treatment from managers. Thus, a growing body of research-based evidence shows that some leaders behave in a destructive manner, either towards their subordinates (Tepper 2007; Bies and Tripp 1998; Tepper 2000) or towards the organisation itself or towards both (Kellerman 2004; Vredenburgh and Brender 1998).

Ethical CEO leadership has been linked with an ethical organisational environment (Shin 2012) and logically the reverse would hold true. Corporate psychopaths are reported to be both unethical managers and abusive supervisors (Boddy et al. 2010; Boddy 2011b), and therefore, their behaviour in CEO positions is of some importance to understand. This importance is emphasised by the knowledge that psychopaths, as around $1 \%$ of the adult population, are reported to be responsible for about $50 \%$ of all serious crimes (Hare 1999) and constitute $20 \%$ of (North American) prison populations (Hare 1999, p. 87).

If corporate psychopaths are as prolifically destructive as their criminal peers are, and initial evidence suggests that they are prolifically destructive, for example, in terms of the regular, frequent bullying of multiple victims (Boddy et al. 2015; Boddy 2014), then the study of their behaviour may yield significant insights into the causes of corporate misbehaviour. Who corporate psychopaths are is discussed below.

\section{Corporate Psychopaths}

Psychopaths are those people representing about $1 \%$ of the population who have no conscience (Coid et al. 2009; Stout 2005) and who demonstrate a predatory and parasitic approach to life (Hare 1994, 1999). This appears to be related to brain functionality differences in psychopaths 
(Anderson and Kiehl 2012). In particular, research by Fallon (2013) and others has repeatedly indicated that psychopathy is related to dysfunction in the amygdala (Weber et al. 2008; Anderson and Kiehl 2012; Blair 2008). This is a part of the brain which regulates emotions (Fallon 2013).

Corporate psychopaths are therefore simply those psychopaths who exist successfully (Smith et al. 2014) in society and work within corporations (Boddy 2006). They are conceptualised as highly career oriented but ruthless, unethical and exploitative employees (Chiaburu et al. 2013; Stevens et al. 2012). Estimations are that while about $1 \%$ of junior employees are corporate psychopaths (assuming a normal distribution of psychopaths in society), they exist at a higher incidence of about $3.5 \%$ at senior organisational levels (Babiak et al. 2010).

These percentages may be higher in certain types of organisation than they are in others, as corporate psychopaths are thought to gravitate towards organisations where they can gain power, money and prestige rather than to the less well-remunerated caring professions (Boddy 2010). Psychopaths have been found to be more common in some organisations rather than others including as CEOs and as lawyers (Dutton 2013a; Lilienfeld et al. 2014; Dutton 2013b). This level of incidence results in between $5.75 \%$ and $13.5 \%$ of employees working with a corporate psychopath at any one time (Caponecchia et al. 2011; Boddy 2011b).

In the interests of balance it should be noted not all commentators believe that workplace psychopathy is "real", important or necessarily negative. For example, Caponecchia, Sun and Wyatt seek to dismiss the importance of psychopaths in the workplace and report that psychopaths are only $0.6-1.2 \%$ of the population. However, their finding that $13.4 \%$ of their sample (Caponecchia et al. 2011) rated a colleague as psychopathic supports the view that psychopaths in the workplace are fairly commonly encountered. Other commentators suggest that psychopathy may be beneficial to organisations and the following papers and articles should be studied for further details of this alternate viewpoint (Smith et al. 2014; Crush 2014; Crawford 2013; Lilienfeld et al. 2012). Some other commentators seek to deny that corporate psychopaths are "real" in a valid sense but are rather implied to be some sort of convenient scapegoats for the excesses of capitalism itself (Federman et al. 2009; Gregory 2012). These commentators report that the psychopathy literature denies the role of a cultural matrix of economic circumstances and societal structures in determining individual wrongdoing (Federman et al. 2009).

Addressing these "reality" claims would constitute a paper in itself and in the interests of space the reader is invited to read the papers referenced in the sentence above and to make up their own minds.

\section{Research Method}

This current research reports on a single case study of a charitable organisation in the UK. The research participant (respondent) was encountered by this researcher at a networking event in June 2013 when the discussion turned towards toxic leadership. The respondent described his $\mathrm{CEO}$ as being toxic in many ways that were indicative of psychopathy. This respondent subsequently agreed to be interviewed for this research. The respondent's relatively newly appointed CEO was reported to embody all the ten characteristics of a corporate psychopath as detailed in a measure of corporate psychopathy called the "Psychopathy Measure-Management Research Version 2" (PM-MRV2). This measure asks a colleague of the subject (where the subject is typically a current manager) to rate the subject on a range of items related to psychopathy. In particular, it asks whether the subject is initially charming, poised and calm, untruthful, cheating, egocentric, remorseless, emotionally shallow, interpersonally unresponsive, irresponsible and lacking in self-blame.

A case study methodology entails the choice of what is to be studied rather than how it is to be studied but it can be qualitative in nature (Stake 2000) as it is in this current research. The case studied here is that of an individual organisation that happened to have a current CEO who was psychopathic and a previous CEO who was reportedly authentically transformational.

It is thus to some extent, a comparative case study of how a psychopathic CEO and an authentically transformational CEO had different effects on organisational outcomes. Individual case studies can provide good initial indications for the directions future research can go and have been undervalued in terms of their ability to generate theoretical generalisations (Tsang 2014). For example, in the natural sciences, the case of finding the penicillium fungi exuding a substance (penicillin) that acted as an antibacterial agent in one Petri dish, was enough to spark generations of medical research into penicillin's (at this stage) theoretical properties vis-à-vis other types of bacteria. The usefulness of the initial case study was arguably enhanced because of the relative stability of the properties of penicillin. Similarly, Babiak's report of a corporate psychopath manipulatively rising, despite opposition, through the ranks of one organisation has stimulated further research into what else corporate psychopaths may get involved in and how else they may behave (Babiak 1995). The psychopathic personality is a fairly stable one over time (Lynam et al. 2007; Forsman et al. 2008) and corporate psychopaths have been observed to have a common modus operandi (Boddy et al. 2015). Thus, individual case studies of how one psychopathic CEO behaves may be 
highly informative in terms of how other corporate psychopaths will behave once they reach CEO positions.

In terms of measuring psychopathy, Lilienfeld and others have argued that researchers need to develop measures of psychopathy that are uncontaminated by antisocial behaviour (Lilienfeld 1994; Cooke et al. 2004) because of the confounding of criminality and psychopathy. The PM-MRV2 attempts to achieve this by focussing on the essential or underlying traits of the psychopathic personality.

The measure is based on the seminal work of Hervey Cleckley in describing the characteristics of those psychopaths who may be found living successfully undetected in society and within organisations such as hospitals, engineering companies and universities (Cleckley 1941/1988).

In this current research, the predecessor of the psychopathic CEO reportedly demonstrated none of the (negative) characteristics of psychopathy and so a comparison of the effects of their respective leaderships on the organisation concerned could be made. The predecessor was rated as scoring 2 (i.e. as non-psychopathic) on the psychopathy scale used as he was said to be charming, apparently intelligent as well as being calm and poised. The current CEO was rated as scoring ten (out of ten) on the same psychopathy scale (i.e. as being highly psychopathic) by the respondent. To ensure a measure of validity, a co-manager of the respondent, who had also worked with the CEO for about 2 years, rated the CEO on the same psychopathy measure. The CEO was again rated as a corporate psychopath.

The respondent was a senior manager at the organisation. This manager was present during the reigns of both CEOs. After the initial meeting, the respondent was interviewed in two separate in-depth interviews concerning the organisation concerned, which was a UK charity. This respondent also replied to two follow-up sets of questions by e-mail concerning the two CEOs. The first in-depth interview was conducted in September 2013 with a followup e-mail in March 2014 and mainly concerned the CEO psychopath. The second in-depth interview was undertaken in July 2014 with a follow-up e-mail the same month and concerned the predecessor to that CEO. The interviews were taped and full transcripts made.

Analysis was made of the emerging and consistent themes evident in the transcripts (Braun and Clarke 2006; Glaser 1969) along the lines of constant comparison suggested by the use of grounded theory research (Glaser and Strauss 1967a, b; Miller and Fredericks 1994). However, this was a relatively simple task because of the limited nature of the data collected, representing as it does a single case study. Nonetheless, case study research can be illuminating. Researchers have noted, for example, how through the narrative of a case study, valuable insights can be gained into the operations and nuances of highly toxic leaders (Goldman 2006), into bullying (Vickers 2001) and psychopaths at work (Babiak 1995) and how such toxic leadership impacts an organisation (Clarke 1993).

Some details of the charity concerned have been changed in order to protect the name and reputation of the charity and the identity of the respondent and the psychopathic CEO involved. In line with qualitative practice in some disciplines (Goodyear 1998), the respondent was given a copy of the paper prior to publication to (i) make sure it was suitably disguised and anonymous, and (ii) to gain an additional element of triangulation via the gaining of an opinion on the validity of the findings and the conclusions made. The respondent agreed that the paper represented a true and valid version of his experience of working under a psychopathic CEO.

\section{Research Findings}

The psychopathic CEO was found to rule via fear and intimidation and to deny any real voice to those working under him. In contrast, the previous CEO encouraged and facilitated employee suggestions and contributions to both organisational tactics and strategy.

Employees who are given a voice in organisational discussions and decisions tend to be positive towards the organisation and to demonstrate a variety of positive behaviours towards that organisation-assuming that their voice is given due consideration (de Vries et al. 2012). When employee voice is cut off therefore, as it was with the corporate psychopath $\mathrm{CEO}$, then positive behaviour towards the organisation may be expected to be notable for its absence. This was reported to be the case in this research where any questioning of the psychopathic CEO's decision making was strongly discouraged.

For example, board meetings became mere "rubber stamping" exercises in terms of approving the position papers distributed beforehand by the CEO. Another example of a diminution of voice among senior managers was that shortly after appointment the CEO convened a working group to look at organisational strategy. However, instead of appointing a variety of staff including senior directors to the group he only asked junior staff and middle managers. These junior employees were reported to be easy to manipulate towards the CEO's point of view.

What I drew from that was that he liked to have teams around him that always said 'yes' and followed and would not answer back. When he said it had to go a certain way, we all went that way. That was not a particularly successful working group. (First in-depth interview 2013)

He just has this toxic influence on the whole office. ....He pulls together small project groups to discuss 
and agree things without getting the people involved that really matter. (First in-depth interview 2013)

This aspect of behaviour had reportedly changed a little by the time of the second interview nine months later. The respondent was of the opinion that the $\mathrm{CEO}$ had been given advice about his undemocratic management style, as a result of some of the employee complaints made about the CEO. The CEO was now reported to seek out different views from employees before making strategic and other decisions. Such behaviour is reported to be typical of transformational leaders (Avolio et al. 1999). However, further probing of this behaviour revealed that the views sought from other employees were often of a tactical rather than strategic nature (for example, what brand of photocopy machine to buy) and in any case these views were routinely ignored in the final decisions made by the psychopathic CEO. No further discussion concerning such decisions was entered into with other employees and there was reportedly no reasons given by the psychopathic CEO why the views of employees (as captured, for example, in employee surveys) were ignored.

In other words, the CEO was not authentic in his seeking out the views of other employees but was only going through the motions of authentic leadership.

This was reported to be in marked contrast to the previous (authentically transformational) CEO who would seek out others' opinions and then only go against the consensus if he held very strong contrary opinions. These would be aired and discussed so that when apparently contrary decisions were made, everyone knew why they had been made. The previous (authentically transformational) $\mathrm{CEO}$ was reported to be approachable, with an open door office policy, but to also have an air of seriousness about him and to concern himself with the big picture or strategic issues rather than the minutiae of the organisation.

Well I think with the previous leader he commanded respect from the staff. A visual of that is he had his own office but the door was always open and you could always approach him....there was the boundary, there was the office. Like I say the door was generally open or ajar so you could go in, he was approachable, but there was that boundary that he was there leading the organisation and making strategic plans. He wasn't sharing all these little things. He was there for the bigger picture stuff. That was a visible illustration of how he commanded respect from the organisation. (Second in-depth interview, 2014)

This was said to be markedly different from the psychopathic CEO who reportedly sits in an open-plan office even when discussing sensitive and confidential issues.
The new leader sits out in open office, in the middle of a busy, vibrant office and has conversations that are clearly confidential and should be within an office with a door closed. He is aware of that but rather than taking it into a private space he is whispering below the panel around the desk.

I sat very close to him and I was embarrassed. It was almost like, I can only compare it to seeing your parents kissing or something like that. It was that much of a cringe. You are talking about serious staff issues here, about recruitment or something like that, with your PA and I can hear everything because I am sitting opposite and you are making no effort other than a little whisper. It was almost childish in its approach. (Second in-depth interview, 2014)

The previous CEO was reported to be less of a good public speaker than the psychopathic CEO but to have been inspirational and motivating. He was reported to be good at delegating work to those below him so that he could concentrate on the strategic issues of the organisation. This authentic CEO drew respect and admiration from employees who would follow him "to the moon and back", while the psychopathic CEO could not even get employees to follow him to the local pub. The previous CEO was also reported to have surrounded himself with a strong, capable and motivated leadership team of directors and senior managers. This was in contrast to the dysfunctional, semiabsent and incapable leadership team which the psychopathic CEO had gathered around himself.

The previous leader, he wasn't the world's best public speaker.... but he employed the right people. He got the right people to surround him and support him and he was a confident, inspirational leader. So the people that worked for him would follow him to the moon and back and the level underneath him, the directors, they were the ones that were making everything happen in the organisation. So he really inspired them to do a great job and actually do the work whilst he was seeing the future and steering the future of the organisation. He was a great strategist but they would do the detail and the ops stuff. (Second in-depth interview, 2014)

The previous CEO was reported to have invited challenge, discussion and constructive criticism towards strategic decisions. In contrast, any voices raised against the views of the psychopathic CEO were reportedly not tolerated. Such viewpoints were denied exposure by the CEO talking over them and not allowing them to be heard, or by not allowing them to speak in the first place. This is illustrated by the quotes below. 
(With) One female... director... he walked (all) over her in meetings, wouldn't allow her to speak to other directors when they had board meetings and so on and talked over her and made her life a living hell until, bless her, she decided the best thing for her to do was to sign a compromise agreement and leave. (First in-depth interview 2013)

Compare that to the previous leader, he was very, very good at challenging you and getting you to use left brain, I think you'd call it, to be reflective and most of the conversations I had with him he would say 'to play Devil's Advocate' to challenge me to a different way of thinking about it. (Second in -depth interview 2014)

Discussion in general was reportedly discouraged by the psychopathic CEO who pre-arranged "discussion" papers for people to agree with in various meetings including board meetings and staff meetings. This CEO reportedly said that such discussions were a waste of time as the comment below illustrates.

You are never allowed to discuss an issue; apparently according to him discussion is just a complete waste of time. Present a paper beforehand, if the paper hasn't been read tough luck. We agree the paper during the meeting and move on. ...(He would say) 'We are not discussing this. Do you agree with the paper or not?' Those who disagreed with the paper were told, this is the way we are having it. (First in-depth interview 2013)

The psychopathic CEO's need for control was reportedly so great that he could not even tolerate, without displaying hostility, a position where one manager disagreed with him while still agreeing to conform to the CEO's plans.

This particular issue came up and I said, 'I disagree with you', to the (psychopathic) Chief Executive. He said, 'well I am making a decision on this'. I said, 'well that's fine, I disagree with you'. He said, 'but you've got to agree with me because I am the boss'. I said 'no I don't have to agree with. I have to do what you say because you are the boss and you pay me but I don't necessarily have to agree with you and on this issue I don't'. He slammed his hand on the table, raised his voice in open office and said, 'you have to agree with me' and then stormed off to his desk. (First in-depth interview 2013)

The psychopathic CEO was reported to want to control every small decision in the office while simultaneously ignoring and not providing leadership on the larger issues of strategy and policy implementation.

The controlling is very much an everyday occurrence. Complete interference with the minutiae of detail ...(with what's) happening here and now, not involved in the vision, the five, the ten year strategic plan at all. (First in-depth interview 2013)

At the same time as being unable to provide leadership and direction to the staff working for him and lacking credibility, the CEO demonstrated no insight into his true abilities, confidently believing himself to be a visionary leader of fantastic abilities.

I think (he can't do his job) absolutely not....I mean the job that he was hired to do he is just not doing. ..... I've had conversations with him recently, as in the last 6 months and he believes he is a fantastic leader, he is a visionary and he is going to move on to bigger and better things...

The guy himself is overly confident in his own ability to, what he thinks is leadership in the organisation. I guess it is like watching a sketch from Fawlty Towers when he is in action. (First in-depth interview 2013)

The reputation for creativity, innovativeness and market leadership that the charity previously enjoyed under the transformational CEO was reportedly totally lost. The charity became a follower rather than a leader, a copier of the ideas and practices of other organisations rather than the instigator of new ideas that other organisations had then copied. Similarly, the leadership ability of the psychopathic CEO was reported to be so low that members of staff could not take him seriously as an organisational leader, leaving a void in the leadership of the organisation. This is illustrated by the verbatim comment below.

He has... lost the respect of the staff if he ever had it in some cases......Nobody takes the guy seriously, like I say, because he has lost all respect of the staff at all levels. (First in-depth interview 2013)

The leadership ability of the psychopathic CEO was reported to be so absent that it was described as being an "organisation without leadership" and as a "lost organisation", one with staff too scared to challenge the aggressive, psychopathic $\mathrm{CEO}$, despite their lack of faith in the CEO's leadership abilities.

Well I believe that there is no direction for the organisation. So as employees we don't know where we are headed. So we are all just running around doing our own things, getting very, very guarded because things aren't going so well, so protecting our own areas and there is no leadership.

........So we are completely lost as an organisation. Nobody dares challenge this guy because he is on a one-to-one basis if you challenge him like I did, you get 'but I am the boss. This is my way'. You have to 
follow me, very, very aggressive in that situation.

(First in-depth interview 2013)

This leaderless situation was reported, in the second indepth interview, to have cascaded down the organisation to the extent that many junior employees had no real leadership available to them. Competent directors had been replaced by the psychopathic CEO, or had left. Experienced senior managers had also left, leaving few experienced managers within the organisation who were able to offer any leadership.

Some junior managers had reportedly "stepped up to the mark" but with no depth of experience of the organisation and no leadership from above, they were limited in what they could achieve. The quote below illustrates the lack of leadership at the top and how it permeated downwards through other directors to more junior staff.

What now emerges I think that that team that he has created... are also quite dysfunctional. ....There was no leadership cascaded down to the director level. They were, quite frankly, just doing whatever they pleased and then that was cascaded down to the staff who were totally de-motivated and thought, well why should I come in at nine o'clock? Why should I just have an hour for lunch? I'll take a day off sick every month and so on and so forth. (Second in-depth interview 2014)

Corporate psychopaths are reported to care for themselves but not for the organisation that employs them and this appears to be the case with the psychopathic CEO in this current research. The following comment mentions a lack of care for the organisation and a lack of leadership and control.

So there are no controls from the top..... cascading down because there is no leadership or care for the organisation or the staff at the top that is cascaded down to the director level. (Second in-depth interview 2014)

After 3 years of the psychopathic CEO being in place, employees were reported to be cynical about the organisation and its leadership.

We've got this guy who thinks he is a visionary telling the Trustees, the head of the Trustees, he is telling them that everything is going fine and dandy. The Trustees are then regurgitating that to the staff and the staff are just all so cynical about it. (Second in-depth interview 2014)

A lack of management ability and leadership ability was evident in the psychopathic CEO and this was compared to the previous CEO. For example, it was reported that bottlenecks of information would be sorted out under the previous CEO by calling every relevant employee into the boardroom and getting to the bottom of the problem through $10 \mathrm{~min}$ of discussion. Under the psychopathic $\mathrm{CEO}$, similar problems were reported to go for months without resolution, with some issues never resolved at all.

The lady who I report to, she has told me because I raise issues, she said that she cannot challenge him on anything. She can't take anything to the leader and get any form of response; all she gets back is 'just deal with it.' So no guidance, just 'deal with it. (Second in-depth interview 2014)

Employees were reported to have lost their enthusiasm for their jobs, and to have become aimless and directionless in terms of their workplace activities. Where possible, employees were reported to be abandoning the leaderless organisation as quickly as they could. A large minority of employees were reported to be leaving without further jobs to go to, which indicates the strength of their desire to leave such a hostile, leaderless and directionless organisation.

We are an organisation of around 70 staff. Our Chief Exec, the potential corporate psychopath, has been with us just under 2 years. The 60th person handed their notice in about 2 weeks ago. So that is 60 out of 70 who have left. (First in-depth interview 2013)

By the time of the second in-depth interview, turnover was reported (including the imminent departure of the respondent) to have exceeded $100 \%$, as recently hired employees were also leaving once they realised the type of leadership and lack of direction of the organisation. The respondent reported that typically employees would realise that the organisation was in trouble after about 3 months of being there and would seek other jobs within a year. The respondent reported that about a third of employees left with no further work to go to (at a time of relative economic stagnation in the UK economy).

I haven't jumped ship like a lot of people and a lot of people have left without jobs to go to. One of them handed in their notice last week without a job to go to. I would say that one in three that have left, a third of those who have left haven't got anything to go to. They've just decided to leave. (Second in-depth interview, 2014)

Other effects of the lack of leadership were reported to be a decline in the financial position of the organisation and in the strength of its resources in general, including in revenue, increased staff withdrawal and turnover, a decline in morale and a lack of direction and leadership in general.

So there is the finance issues, there is the staff turnover and then the staff turnover struck morale and 
then a lack of direction and leadership. (First indepth interview 2013)

I am the current longest serving member of staff.....I have become totally disillusioned (and handed in my notice of resignation). (Second in-depth interview, 2014)

Leadership was reported to be not only conceptually and intellectually absent with the psychopathic CEO but physically absent as well. Directors and managers would frequently be off work with stress-related illnesses, and the CEO would often be at home and consequently no one would be in charge within the office environment. Employees would engage in social activities, surf the internet or just mess around with no one to guide or direct their activities.

This was also evident from the second in-depth interview. Leaderless-ness was still reportedly marked by an absence of direction and leadership. The psychopathic CEO was reported to be absent when needed and the remaining directors were unwilling or unable to make decisions in his stead. In marked contrast, the previous CEO was reported to have been a transformational leader of great ability and of sufficient confidence in his own abilities to ask employees to challenge the norms and the status quo, to invite questions, stimulate debate and inspire creativity among other employees.

Everybody respected the previous Chief Exec because he would always challenge. He would always challenge but he would expect you as a staff member to challenge. He didn't expect you to agree with him on anything and he always invited the challenge and he respected good ideas. Now this (new) guy does not respond at all well to any suggestion, any idea, heaven forbid any question of a challenge. It is cut down publicly. No that is not the way we are doing it. We are doing it like this. This is my way. This is the way we are doing it. I am running this show not you. I have heard... words come out of his mouth. 'I am the Chief Executive not you,' to a director previously in a meeting. So, (he is) all-controlling in the organisation. (First in-depth interview 2013)

Transformational leaders are reported to embody characteristics that make employees proud to serve under them and respect them (Avolio et al. 1999) and this was reported to have been the case with the previous CEO. The previous CEO was reported to have displayed confidence albeit in a less extroverted manner than the current CEO and this confidence is again characteristic of a transformational leader (Avolio et al. 1999).

The lack of current leadership was reported to be among the factors involved in the decline in creativity, challenge and innovativeness in the organisation and the concomitant increase in staff leaving. One director who was reported to be extremely talented, a visionary and true strategist was reported to have left without even a new job to go to because they could not bear to work in such a hostile environment entailing poor and missing leadership.

The comment below illustrates the view that the organisation had become mediocre and had lost its position as a thought leader because of the lack of leadership displayed by the psychopathic CEO.

Whereas now we are encouraged to continue doing what we are doing, perhaps look at what other people are doing and copy that rather than being the thought leaders that we have been in the past. Unfortunately because of that we are losing skilled members of staff. We are haemorrhaging staff... and it seems that every time somebody leaves, somebody with a particular skill set, be it web, be it data, be it creative, be it event organisation, whatever it might be, those creative people are being stifled and they are the ones... leaving. (First in-depth interview 2013)

This was also evident in the second interview as demonstrated in the comment below which talks about the good team building capability of the previous CEO compared to the psychopathic CEO.

The old boss, what he was very good at was getting the right people around. I alluded to that with the directors and having good people and the thought leaders. He built great teams. He set us on the direction and we made it happen. Whereas what we've got now is no direction, rubbish leadership team and people just peddling very fast trying to get through the day or through the week and make sure their individual targets or KPI's are met. (Second in-depth interview 2014)

It was also the loss of the other capable members of the leadership team that had reduced the capabilities of the organisation under the psychopathic CEO.

Well we were... the thought leaders at that time. We had some great people who could be classed as visionaries because of their outspokenness about how the sector is going to change and what we need to do to support it. (Second in-depth interview 2014)

The psychopathic CEO had, through two re-structures within 3 years, reduced the number of other directors to four. Three of these directors were described as useless and one as a time server. Corporate psychopathy theory would suggest that such directors would be attractive to a psychopathic CEO because they would be easy to control because of their lack of ability, lack of interest and lack of objectivity in terms of their dependence on the CEO for 
their appointment. This allows the corporate psychopath to have an unchallenged and unchallenging role in the organisation.

(One director) is settling into retirement, he's got his head in the sand, he is not interested in anything new or challenging, just hit your target. The people who work for him are not necessarily well motivated to do a great job because it is just a case of just hit the target, just hit the target. The other two that have been recruited by our current leader are completely useless. (Second in-depth interview 2014)

Stress-related illnesses due to a lack of leadership and a bullying environment were reported to be a factor in the decline of the organisation's performance as the comment below illustrates. Absence due to illness was reported to have gone from a once-a-month occurrence for a single employee under the transformational CEO to a daily occurrence for four employees under the psychopathic CEO.

Assuming a 240-day working year (48 working weeks per year times 5 working days per week), then this represents an increase in absence due to illness from 12 times per year to at least 960 times per year, an increase of $8000 \%$.

There is no direction and leadership from the top so (with) the bullying from the threats to his immediate reports...we have at least $10 \%$ and up to $20 \%$ staff off ill on any one day. So there will be emails in my inbox right now that say this person isn't in today because they are ill. (First in-depth interview 2013)

Corporate psychopathy theory, supported by some evidence from an Australian study of managers working under a corporate psychopath (Boddy 2011c) hypothesises that workload will increase under corporate psychopaths because of their inability or do their own jobs and unwillingness to train others. The verbatim comment below supports this viewpoint because under the "leadership" of the psychopathic CEO, even insignificant job tasks like signing a manager's expense reports were postponed because of the apparent lack of time of the director concerned.

I walk over with an expense sheet to be signed, as an example, the hand is up, flat palm to my face, 'go away from my desk. I am too busy to deal with you today'. I am one of six people who report to that lady and it is hostile absolutely hostile...... she feels.. she is getting no support from above ... So in her first year she had 7 weeks off due to stress caused by the job and her retaliation to that now is to just manage her time and by managing her time is to say to me and others, I am too busy, I can't deal with you today. (Second in-depth interview 2014)
A change in the atmosphere of fear within the organisation was somewhat evident by the time of the second interview and one reason given for this was that the psychopathic CEO was now seen as an incompetent leader. He was seen as someone who employees could not be proud of and who was undeserving of respect. The committed and dedicated employees who were there before the new CEO was appointed had all left. Many of the remaining employees were now unafraid of being disciplined because they were largely uncommitted to the organisation and uncommitted to its leadership. However, an atmosphere of hostility and uncooperation was still reported to exist as the comment above illustrates. Indeed by this stage, the previous CEO was reported to have inspired more fear than the current CEO which would at face value be seen as counter-indicative to the previous CEO being a transformational leader. However, further investigation of this issue threw some interesting light on it. When asked why the previous CEO inspired more fear than the current CEO now did, the respondent reported that, as an example, if the previous CEO had caught an employee spending time on long personal telephone calls then that employee would have been gently reprimanded for it. Under the current CEO, people reportedly spent up to $30 \%$ of their time at work undertaking personal activities such as playing internet games, sending text messages to their friends and drinking coffee in local cafes. There was reportedly no discouragement from the organisational leadership for undertaking such activities.

\section{Discussion}

Corporate psychopaths are reported to be highly manipulative individuals who charm their way into senior positions that are in reality above their ability and qualifications to undertake (Boddy 2011a). In this research case study, the leadership abilities of the psychopathic CEO concerned were reported to be absent, resulting in a state of leaderless-ness marked by a lack of direction and staff aimlessness. This is not an ethical stewardship (Caldwell et al. 2008) type of leadership because the actions of the psychopathic CEO are not congruent with the supposed organisational values of the charity. Ethical stewardship would involve the honouring of leadership duties owed to employees, stakeholders, and society and this was simply not taking place. The psychopathic CEO did not earn the trust, respect and commitment from employees that a leader who was an ethical steward would be expected to generate (Caldwell et al. 2010).

Dissent and questioning are not tolerated by corporate psychopaths, as they seek to protect their own agenda from discovery. In line with this, in the current case study a near total intolerance towards any sort of questioning of the 
psychopathic CEO was evident. Fear, abuse and bullying, all found as characteristic of the presence of Corporate Psychopaths (Boddy 2011b, 2013a) was evident in this case study, with many employees being too intimidated to question the actions of the inept but psychopathic CEO.

In support of a social exchange perspective, leadermember exchange has been related to positive employee behaviour in the workplace such as citizenship behaviour (Wayne and Green 1993). Conversely, negative reciprocity (Biron 2010) may act to foster negative employee behaviour in the workplace and this is what was found in this case study. Examples of aimless loitering, malingering, withdrawal and general listlessness were reported in the presence of psychopathic leadership.

This finding is also in line with research which examined the relationships between violations of employees' psychological contracts and their behaviours towards loyalty, leaving and neglect (Turnley and Feldman 1999). The denial of voice (Kim et al. 2010), purpose and leadership to employees found in the current research, together with the bullying that was evident, may be viewed as a breaking of the psychological contract (the unwritten rules and mutual expectations) (Parzefall and Salin 2010) between employees and their employing organisation.

Abusive and bullying supervision affects employees in terms of both work and personal behaviour (Bamberger and Bacharach 2006) and corporate psychopaths have been linked to abuse and bullying (Boddy 2011b, 2013a). It is not a surprise therefore that the psychopathic CEO in this case study was associated with changes in employee behaviour at work such as taking longer breaks and sickness absences. Bullying, as was evident in this case study, is also related to turnover intention (Houshmand et al. 2012) and indeed turnover in this case was in direct relation to the bullying CEO.

Arguably corporate psychopaths like the CEO investigated in this current research may be seen as "impostors" in business (de Vries 1990) because they do not have the leadership abilities and competencies that they claim to have on appointment. Corporate Psychopaths have been found, for example, to claim qualifications like MBA degrees that they have not earned.

Further, psychopaths are reported to have an orientation towards social dominance (Lee et al. 2013; Jonason et al. 2014; Jones and Figueredo 2013) and a social dominance orientation is in turn related to some counterproductive workplace outcomes (Shao et al. 2011). Such outcomes were found in this research.

A level of employee cynicism towards the CEO leader was evident in this current research and this corresponds with other studies which find that perceived senior management credibility, employee cynicism and outcomes are related (Kim et al. 2009). In this research, it was evident that at least after the 2-year period of tenure enjoyed at the time of the first interview, the psychopathic CEO had no credibility within the organisation. He was viewed as a "Fawlty Towers" type of character with no genuine leadership skills. This had not changed at the time of the second in-depth interview but the fear he inspired had abated to some extent in tandem with a rising indifference to the fate of the organisation among employees, and thus, a decline in attempts to challenge the direction of the psychopathic CEO.

Commentators on leadership have conjectured that sustained organisational functioning is more likely to be the result of a leader possessing humility (Morris et al. 2005). This is certainly supported by this current research because the inept but self-important psychopathic CEO reportedly generated an organisation that was disintegrating both financially and in terms of its human resources, who were leaving. On the other hand, the humble but accomplished predecessor to the psychopathic CEO was reported to have presided over an organisation that was thriving in many different ways.

The graph below (Fig. 1) is an illustrative delineation of the broadly defined performance (including innovativeness, creativity, authentic leadership and revenue) of the UK charity under a psychopathic CEO appointed at "Year 6.5".

After the psychopathic CEO was appointed, performance was perceived to have declined within weeks. Under the previous (authentic) CEO, the perceived and actual performances were reported to be synchronous. After appointment, the corporate psychopath CEO portrayed a glowing picture of apparent success to the board of trustees, while managers within the organisation perceived a continuous decline in fund raising innovativeness, creativity, direction, authentic leadership and revenue.

As a result of the atmosphere of bullying, confusion and apparently aimless, directionless leadership, within

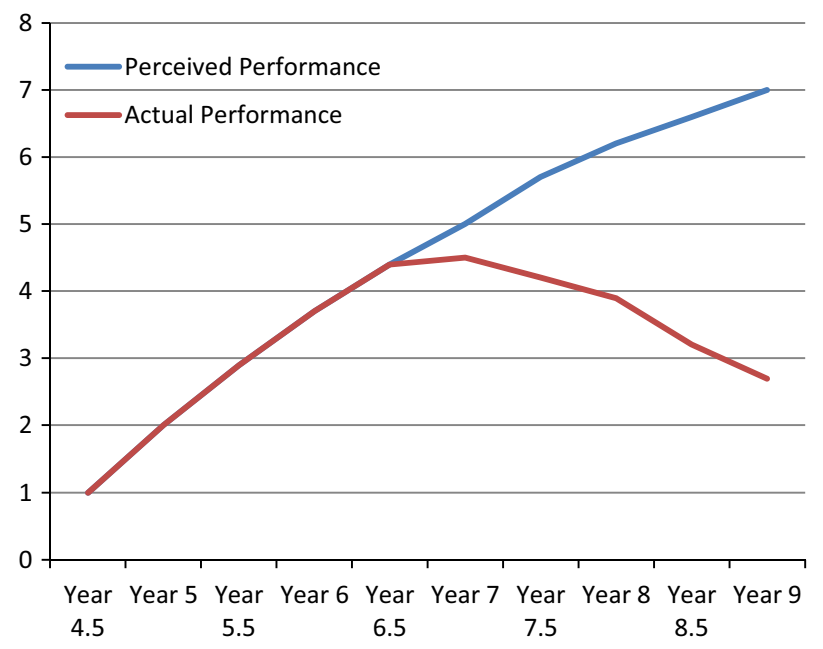

Fig. 1 Performance under a psychopathic CEO 
10 years $100 \%$ of the original staff had left the organisation or had resigned and were about to leave. This left new staff with almost no experienced managers to learn from and resulted in a downward shift in performance capability.

The gap in performance between actual and perceived is assumed to be unsustainable in the medium to longer term because, as was apparent in organisations like Enron, financial figures can only be massaged for so long before the truth of the situation becomes increasingly apparent. The prediction from corporate psychopathy theory is that the corporate psychopath CEO will go on to "bigger and better" roles in other organisations before the performance gap at the charity becomes apparent.

Senior executives are reported to give the organisation's 'tone at the top' (Treviño et al. 2003). In line with this viewpoint in this current case study, the CEO reportedly generated a culture of hopeless indifference to the fate of the charity concerned. As a result, employees in this case study reportedly felt disenfranchised and disempowered. Empowerment has been linked to positive outcomes (Raub and Robert 2010) and so it is arguably no surprise that negative outcomes were evident in the case of a disempowering psychopathic CEO as leader.

At the second interview, the agenda of the CEO in taking the appointment was reported to have become evident to the respondent. The CEO planned to move to a "bigger and better" position but had little previous organisational leadership experience (apart from leading a very small team within a division) and so a CEO position at a charity filled this "gap" in the CV (Boddy et al. 2015).

At the time of the second interview, the CEO had been in place almost 3 years and was reported to be firmly positioning himself for a future career in UK politics where a background in the charity sector would appear to be good credentials for presenting oneself as a caring and genuine individual. Having held an apparently successful leadership post in a socially desirable organisation would also be useful.

I mean I think the Chief Exec it has now become apparent he has political aspirations and all what he is doing for the organisation is to drive that so he is driving his future. (Second in-depth interview, 2014)

This would also explain the CEO's reported obsession with releasing positive press releases and "tweets" concerning the claimed achievements of the charitable organisation under his "leadership".

Staff withdrawal behaviour is reportedly high under corporate psychopath managers (Boddy 2011c) and this research supports this finding because both illness absence and staff turnover increased under the reign of a psychopathic CEO. Under a psychopathic CEO, employees are dissatisfied with their jobs, become increasingly lacking in commitment and ultimately withdraw from and leave the organisation.

Job satisfaction and commitment to an organisation are also linked to the presence of toxic leadership (Mehta and Maheshwari 2013; Lipman-Blumen 2005) as are selfish outcomes that are detrimental to organisational efficiency (Tavanti 2011) and as may have been expected, these outcomes were evident in this current research.

Employee well-being decreases and stress and distress are reported to increase under managers or supervisors who are corporate psychopaths (Mathieu et al. 2014; Boddy 2013a). This was also found in this current research where illness or absence due to stress was reported at all levels of the organisation. Stress-related absence was reported to be particularly evident at senior levels, among those working closest to the psychopathic CEO, as expected from corporate psychopathy theory (Boddy 2013a).

Transformational leaders are those reportedly able to transform the performance of an organisation in a positive direction (Khoo and Burch 2008; Bass and Steidlmeier 1999) by providing true leadership rather than leaderlessness (McCarthy 1997). Leaderless-ness here is meant as being the state of being without an effective leader.

The current research seems to imply that corporate psychopaths as CEO leaders are, in some important ways, the opposite of transformational because they promote a leaderless organisational environment characterised by a lack of direction and a de-motivated and aimless workforce. Transformational leadership research links, for example, job satisfaction with transformational leaders (Timothy and Gian 2007) and follower attitudes with transformational leadership (Barroso Castro et al. 2008).

This current research is arguably in line with these findings because it establishes that dissatisfaction and negative job attitudes are associated with the presence of a psychopathic CEO who exhibits behaviour which is arguably anything but transformational or authentic (Avolio and Gardner 2005).

The change in the element of fear at work in the organisation concerned was notable in the second in-depth interview. A reason for this from corporate psychopathy theory may be that fear was no longer needed by the CEO to achieve his ambitions. Psychopaths employ violence and intimidation in an instrumental manner, i.e. to get what they want (Blair 2001) and once achieved such behaviour is no longer necessary. In this current case study, a state of directionless indifference had already largely been reached within the organisation and its employees by the time of the second interview, and therefore, there was no longer much for the CEO to be worried about in terms of anyone threatening his position and apparent ulterior agenda. An attempt to un-seat the psychopathic CEO by reporting his behaviour to the board had already failed, and the manager 
concerned was in the process of leaving as the last of the old guard of employees who the CEO had inherited.

\section{Limitations of the Research}

This qualitative research was based on a single case study involving two in-depth face-to-face interviews with a middle-level manager in England and four telephone and e-mail conversations with the same manager over 2 years. Findings may not apply to cases involving countries with very different cultures.

Case studies can, however, be generalised from with greater confidence than many "positivist" researchers usually state (Tsang 2014). This is especially so when the subjects involved (such as psychopaths) display characteristics which are stable over time. A further limitation relates to a possible 'halo effect' resulting from the fact that the respondent worked under a previous CEO who was transformational in behaviour. Because of the extreme differences between the two, the psychopathic CEO may have been seen as more negative than he actually was. However, this CEO was also reported on in terms of psychopathic behaviour, by another manager at the charity. This second rating also scored the CEO as psychopathic enough to be rated as a corporate psychopath.

\section{Conclusion}

This current research re-enforces the view that leadership is of huge consequence in terms of team effectiveness and performance (Hogan and Kaiser 2005) because it illustrates the organisational consequences of the relative lack of leadership under a psychopathic CEO. This included disintegration of teamwork, performance and of organisational effectiveness. The current research also supports the view that personality predicts leadership (Hogan et al. 1994; Hogan and Kaiser 2005) because under the stable personality characteristics of a corporate psychopath, leadership suffers in predictable ways. The appointment of a psychopathic CEO had a number of effects on the organisation but one of the most marked was the impression of leaderless-ness that took place after the initial appointment of the new CEO.

Employees reportedly lacked a leader in terms of their being left to their own devices, not being given direction and not being given hope for the future of their careers within the organisation. Further, they were not being given aims and objectives that were in any sense clearly aligned with the longitudinal success of the charity. Employees were denied a voice in contributing to the running of the organisation under the psychopathic CEO. Employees were also denied the sort of teaching and coaching they could have expected from a more transformational leader, meaning that they were more unsure of what to do or how to do it in the positions they held. Disillusionment set in and staff absenteeism increased from being a single monthly occurrence to a multiple daily occurrence. Staff turnover increased to the extent that $86 \%$ of staff left within 2 years of the initial appointment of the psychopathic CEO and over $110 \%$ had left within 3 years, i.e. the replacement staff was also leaving by then. Conversely under the previous CEO, employees had been given a voice, were coached, mentored and trained and were led strategically.

This research contributes to the literature on leadership because it highlights the effects of leaderless-ness and contributes to corporate psychopathy theory because it illustrates the effects of psychopathic leadership. It is also the first indication that the tactics employed by corporate psychopaths may change over time and that once their initial objectives of submission and control through fear have been achieved, then less bullying and intimidation are needed. Further research could examine this phenomenon through a longitudinal study of how corporate psychopathy evolves over time.

In terms of the corporate governance (Turnbull 1997) aspect of this research and of whether psychopaths should be screened into organisations as reportedly happened in corporate banks (Basham 2011) or out of organisations (Marshall et al. 2015), there is still debate (Smith and Lilienfeld 2013; Boddy 2013b). Some commentators claim that corporate psychopaths are actually good for business (Crush 2014; Crawford 2013; Olster 2012) or are not "real" psychopaths but rather that such labelling constitutes an usurping of psychopathy (Gregory 2012). This case study contributes to this discussion by illustrating some of the negative consequences of the appointment of a CEO who was a corporate psychopath.

The research adds information relevant to the debate on whether corporate psychopaths should be screened into or out of organisations because it re-enforces the view that they are ultimately destructive to the organisations that employ them. An implication of this is that if professionals within human resources want the opportunity to play a greater role in contributing to organisational success (Caldwell et al. 2011), then they may have to start to screen leadership candidates for psychopathy because organisational success and psychopathy are inimical.

Finally, corporate psychopaths are reported to be parasitic in that they feed off the good work of others and this current research confirms this viewpoint. The psychopathic CEO has reportedly strengthened his own position and external reputation while weakening the organisation that employs him, especially in terms of its human resource capability and overall performance. 
Open Access This article is distributed under the terms of the Creative Commons Attribution 4.0 International License (http://crea tivecommons.org/licenses/by/4.0/), which permits unrestricted use, distribution, and reproduction in any medium, provided you give appropriate credit to the original author(s) and the source, provide a link to the Creative Commons license, and indicate if changes were made.

\section{Appendix}

\section{See Table 1.}

Table 1 An example of the type of thematic analysis used to code and sort verbatim responses

\begin{tabular}{|c|c|c|}
\hline Basic themes (codes) & Organising themes & Global themes \\
\hline $\begin{array}{l}\text { Position papers replace } \\
\text { open discussion }\end{array}$ & \multirow[t]{4}{*}{$\begin{array}{l}\text { Employees are } \\
\text { denied a voice }\end{array}$} & \multirow{7}{*}{$\begin{array}{l}\text { Leaderless-ness } \\
\text { (Control of minutia } \\
\text { replaces strategic } \\
\text { leadership) }\end{array}$} \\
\hline $\begin{array}{l}\text { Differences of opinion } \\
\text { are characterised as } \\
\text { dissent }\end{array}$ & & \\
\hline $\begin{array}{l}\text { Alternative views are } \\
\text { over-ridden and } \\
\text { disallowed }\end{array}$ & & \\
\hline $\begin{array}{l}\text { Employee opinions are } \\
\text { ignored }\end{array}$ & & \\
\hline $\begin{array}{l}\text { Reorganisation } \\
\text { reduces the number } \\
\text { of directors from } 8 \text { to } \\
4\end{array}$ & \multirow[t]{3}{*}{$\begin{array}{l}\text { Competent } \\
\text { directors } \\
\text { withdraw or } \\
\text { leave }\end{array}$} & \\
\hline $\begin{array}{l}\text { Stress induces absence } \\
\text { of directors due to } \\
\text { illness }\end{array}$ & & \\
\hline $\begin{array}{l}\text { Competent directors } \\
\text { leave with no job to } \\
\text { go to }\end{array}$ & & \\
\hline $\begin{array}{l}\text { Table thumping in } \\
\text { response to } \\
\text { employee } \\
\text { questioning replaces } \\
\text { a culture of open } \\
\text { discussion }\end{array}$ & \multirow[t]{3}{*}{$\begin{array}{l}\text { Authoritarianism } \\
\text { replaces } \\
\text { authentic } \\
\text { leadership, } \\
\text { efficiency } \\
\text { deteriorates. }\end{array}$} & \multirow[t]{7}{*}{$\begin{array}{l}\text { A climate of fear } \\
\text { induces } \\
\text { organisational } \\
\text { paralysis }\end{array}$} \\
\hline $\begin{array}{l}\text { Employees fear to } \\
\text { question authority, } \\
\text { whereas before they } \\
\text { were asked to } \\
\text { question it }\end{array}$ & & \\
\hline $\begin{array}{l}\text { Managers avoid } \\
\text { decision making }\end{array}$ & & \\
\hline $\begin{array}{l}\text { Alternative views are } \\
\text { met with hostility }\end{array}$ & \multirow{4}{*}{$\begin{array}{l}\text { Abusive and } \\
\text { bullying } \\
\text { leadership }\end{array}$} & \\
\hline $\begin{array}{l}\text { Shouting replaces } \\
\text { discussion }\end{array}$ & & \\
\hline $\begin{array}{l}\text { Employees are } \\
\text { intimidated }\end{array}$ & & \\
\hline $\begin{array}{l}\text { Acquiescence is } \\
\text { encouraged }\end{array}$ & & \\
\hline
\end{tabular}

\section{References}

Aasland, M. S., Skogstad, A., Notelaers, G., Nielsen, M. B., \& Einarsen, S. (2010). The prevalence of destructive leadership behaviour. British Journal of Management, 21(2), 438-452.

Alvesson, M. (1997). Leadership studies: From procedure and abstraction to reflexivity and situation. The Leadership Quarterly, 7(4), 455-485.

Anderson, N. E., \& Kiehl, K. A. (2012). The psychopath magnetized: Insights from brain imaging. Trends in Cognitive Sciences, 16, $52-60$.

Antonakis, J., Day, D. V., \& Schyns, B. (2012). Leadership and individual differences: At the cusp of a renaissance. In Leadership Quarterly, 23, 643-650.

Avolio, B. J., Bass, B. M., \& Jung, D. I. (1999). Re-examining the components of transformational and transactional leadership using the Multifactor Leadership Questionnaire. Journal of Occupational and Organizational Psychology, 72(4), 441-462.

Avolio, B. J., \& Gardner, W. L. (2005). Authentic leadership development: Getting to the root of positive forms of leadership. The Leadership Quarterly, 16(3), 315-338.

Babiak, P. (1995). When psychopaths go to work: A case study of an industrial psychopath. Applied Psychology: An International Review, 44(2), 171-188.

Babiak, P., Neumann, C. S., \& Hare, R. D. (2010). Corporate psychopathy: Talking the walk. Behavioral Sciences \& the Law, 28(2), 174-193.

Baker, M. W. (2013). A multiple case study of the dark side of leadership: An exploration of executives who led their companies to disastrous results versus exemplary CEOs who did not. Regent University.

Bamberger, P. A., \& Bacharach, S. B. (2006). Abusive supervision and subordinate problem drinking: Taking resistance, stress and subordinate personality into account. Human Relations, 59(6), $723-752$.

Barroso Castro, C., Villegas Perinan, M. M., \& Casillas Bueno, J. C. (2008). Transformational leadership and followers' attitudes: The mediating role of psychological empowerment. The International Journal of Human Resource Management, 19(10), 1842-1863.

Basham, B. (2011). Beware corporate psychopaths-they are still occupying positions of power. Retrieved from http://www.indepen dent.co.uk/news/business/comment/brian-basham-beware-corporatepsychopaths-they-are-still-occupying-positions-of-power-6282502. html?origin=internalSearch.

Bass, B. M., \& Steidlmeier, P. (1999). Ethics, character, and authentic transformational leadership behavior. Leadership Quarterly, 10(2), 181-217.

BBC News (2004). Is your boss a 'corporate psycho'? Retrieved from http://news.bbc.uk/go/pr/fr/-/hi/business/3392233.stm.

Bies, R. J., \& Tripp, T. M. (1998). Revenge in organizations: The good, the bad, and the ugly. In R. W. Griffin, A. E. O'LearyKelly, \& J. M. Collins (Eds.), Dysfunctional behavior in organizations: Violent and deviant behavior. Monographs in organizational behavior and industrial relations, parts $A \& B$ (Vol. 23, pp. 49-67). Greenwich: Elsevier Science/JAI Press.

Biron, M. (2010). Negative reciprocity and the association between perceived organizational ethical values and organizational deviance. Human Relations, 63(6), 875-897.

Blair, R. J. R. (2001). Neurocognitive models of aggression, the antisocial personality disorders, and psychopathy. Journal of Neurology, Neurosurgery and Psychiatry, 71(6), 727-731.

Blair, R. (2008). The amygdala and ventromedial prefrontal cortex: Functional contributions and dysfunction in psychopathy. Philosophical Transactions of the Royal Society B: Biological Sciences, 363(1503), 2557-2565. 
Boddy, C. R. (2006). The dark side of management decisions: Organisational psychopaths. Management Decision, 44(9/10), $1461-1475$.

Boddy, C. R. P. (2010). Corporate psychopaths and organizational type. Journal of Public Affairs, 10(4), 300-312.

Boddy, C. R. (2011a). The corporate psychopaths theory of the global financial crisis. Journal of Business Ethics (Vol. 102, pp. 255-259). Netherlands: Springer.

Boddy, C. R. (2011b). Corporate psychopaths bullying and unfair supervision in the workplace. Journal of Business Ethics, 100, $367-379$.

Boddy, C. R. (2011c). Corporate psychopaths: Organisational destroyers. Basingstoke: Palgrave Macmillan.

Boddy, C. R. (2013a). Corporate psychopaths, conflict, employee affective well-being and counterproductive work behaviour. Journal of Business Ethics, 121, 1-15.

Boddy, C. R. P. (2013b). Corporate behaviour and corporate psychopaths. In Improving corporate behaviour. London: British Academy of Management, Westminster Palace.

Boddy, C. R. (2014). Corporate psychopaths conflict, employee affective well-being and counterproductive work behaviour. Journal of Business Ethics, 121(1), 107-121.

Boddy, C. R. P., Ladyshewsky, R., \& Galvin, P. (2010). Leaders without ethics in global business: Corporate psychopaths. Journal of Public Affairs, 10(3), 121-138.

Boddy, C. R., Miles, D., Sanyal, C., \& Hartog, M. (2015). Extreme managers, extreme workplaces: Capitalism, organisations and corporate psychopaths. Organization, 2(4), 530-551.

Braun, V., \& Clarke, V. (2006). Using thematic analysis in psychology. Qualitative Research in Psychology, 3(2), 77-101.

Caldwell, C., Hayes, L., Bernal, P., \& Karri, R. (2008). Ethical stewardship: Implications for leadership and trust. In Journal of business ethics, vol. 78, pp. 153-164. Netherlands: Springer.

Caldwell, C., Hayes, L., \& Long, D. (2010). Leadership trustworthiness, and ethical stewardship. Journal of Business Ethics, 96(4), 497-512.

Caldwell, C., Truong, D., Linh, P., \& Tuan, A. (2011) Strategic human resource management as ethical stewardship. In Journal of business ethics, vol. 98, pp. 171-182. Netherlands: Springer.

Caponecchia, C., Sun, A., \& Wyatt, A. (2011). Psychopaths' at work? implications of lay persons' use of labels and behavioural criteria for psychopathy. Journal of Business Ethics, 107(4), 399-408.

Chiaburu, D. S., Muñoz, G. J., \& Gardner, R. G. (2013). How to spot a careerist early on: Psychopathy and exchange ideology as predictors of careerism. Journal of Business Ethics, 118(3), 473-486.

Clarke, T. (1993). Case study: Robert maxwell: Master of corporate malfeasance. Corporate Governance: An International Review, 1(3), 141-151.

Cleckley, H. (1941/1988). The mask of sanity, 5th edn, Private printing for educational use by Emily Cleckley 1988 (Formerly first published by C.V. Mosley Co.in 1941), Augusta.

Coid, J., Yang, M., Ullrich, S., Roberts, A., \& Hare, R. D. (2009). Prevalence and correlates of psychopathic traits in the household population of Great Britain. International Journal of Law and Psychiatry, 32(2), 65-73.

Cooke, D. J., Michie, C., Hart, S. D., \& Clark, D. A. (2004). Reconstructing psychopathy: Clarifying the significance of antisocial behavior in the diagnosis of psychopathic personality disorder. Journal of Personality Disorders, 18, 337-357.

Crawford, A. (2013). The pros to being a psychopath. Retrieved 14 Mar 2013 from at http://www.smithsonianmag.com/sciencenature/The-Pros-to-Being-a-Psychopath-176019901.html.

Crush, P. (2014). Every business needs a psychopath. In People management (CIPD) de Vries, K. (1985). Narcissism and leadership: An object relations perspective. Human Relations, 38, 583-601.

de Vries, M. F. R. K. (1990). The impostor syndrome: Developmental and societal issues. Human Relations, 43(7), 667-686.

de Vries, G., Jehn, K. A., \& Terwel, B. W. (2012). When employees stop talking and start fighting: The detrimental effects of pseudo voice in organizations. Journal of Business Ethics, 105(2), $221-230$

Dutton, K. (2013a). Wisdom from psychopaths. Scientific American Mind, 23(6), 36-43.

Dutton, K. (2013b). The wisdom of psychopaths. New York: Random House.

Fallon, J. (2013). The psychopath inside: A neuroscientist's personal journey into the dark side of the brain. New York: Penguin.

Federman, C., Holmes, D., \& Jacob, J. D. (2009). Deconstructing the psychopath: A critical discursive analysis. Cultural Critique, 72(1), 36-65.

Forsman, M., Lichtenstein, P., Andershed, H., \& Larsson, H. (2008) Genetic effects explain the stability of psychopathic personality from mid-to late adolescence. Journal of Abnormal Psychology, 117(3), 606.

Glaser, B. G. (1969). The constant comparative method of qualitative analysis. In G. J. McGall \& J. L. Simmonds (Eds.), Issues in participant observation: A text and reader (pp. 216-228). Reading, MA: Addison Wesley Publishing.

Glaser, B. G., \& Strauss, A. (1967a). The discovery of grounded theory: Strategies for qualitative research. Chicago: Aldine.

Glaser, B. G., \& Strauss, A. L. (1967b). The discovery of grounded theory. London: Weidenfeld and Nicholson.

Goldman, A. (2006). High toxicity leadership: Borderline personality disorder and the dysfunctional organization. Journal of Managerial Psychology, 21(8), 733-746.

Goodyear, M. (1998). Qualitative research. In C. McDonald \& P. Vangelder (Eds.), The ESOMAR handbook of market and opinion research (4th ed.). Amsterdam: ESOMAR.

Gregory, D. W. (2012). Deconstructing financial psychopaths: Culture, evolution, or opportunity? In The 2012 annual meeting of the academy of behavioral finance \& economics, p. 42. New York.

Gudmundsson, A., \& Southey, G. (2011). Leadership and the rise of the corporate psychopath: What can business schools do about the 'snakes inside'? e-Journal of Social and Behavioural Research in Business, 2(2), 18-27.

Hare, R. (1994). Predators: The disturbing world of the psychopaths among us. Psychology Today, 27(1), 54-61.

Hare, R. (1999). Without conscience: The disturbing word of the psychopaths among us. New York: Guildford Press.

Hochwarter, W. A., \& Thompson, K. W. (2012). Mirror, mirror on my boss' wall: Engaged enactments moderating role on the relationship between perceived narcissistic supervision and work outcomes. Human Relations, 65(3), 335-366.

Hogan, R., Curphy, G. J., \& Hogan, J. (1994). What we know about leadership: Effectiveness and personality. American Psychologist, 49(6), 493-504.

Hogan, R., \& Hogan, J. (2001). Assessing leadership: A view from the dark side. International Journal of Selection and Assessment, 9(1-2), 40-51.

Hogan, R., \& Kaiser, R. (2005). What we know about leadership. Review of General Psychology, 9(2), 169-180.

Hogan, R., Raskin, R., \& Fazzini, D. (1990). The dark side of charisma. In K. E. Clark (Ed.), Measures of leadership (pp. 343-354). West Orange, NJ: Leadership Library of America.

Houshmand, M., O'Reilly, J., Robinson, S., \& Wolff, A. (2012). Escaping bullying: The simultaneous impact of individual and unit-level bullying on turnover intentions. Human Relations, 65(7), 901-918. 
Jonason, P. K., Honey, L. P., \& Semenyna, S. W. (2014). It's good to be the king: How the Dark Triad traits facilitate dominanceattainment in men. Personality and Individual Differences, 60, S17.

Jones, D. N., \& Figueredo, A. J. (2013). The core of darkness: Uncovering the heart of the Dark Triad. European Journal of Personality, 27(6), 521-531.

Kaiser, R. B., LeBreton, J. M., \& Hogan, J. (2013). The Dark Side of personality and extreme leader behavior. Applied Psychology, 64, 55-92.

Kellerman, B. (2004). Thinking about... leadership. Warts and all. Harvard Business Review, 82(1), 40-45.

Khoo, H. S., \& Burch, G. S. J. (2008). The dark side of leadership personality and transformational leadership: An exploratory study. Personality and Individual Differences, 44(1), 86-97.

Kim, T.-Y., Bateman, T. S., Gilbreath, B., \& Andersson, L. M. (2009). Top management credibility and employee cynicism: A comprehensive model. Human Relations, 62(10), 1435-1458.

Kim, J., MacDuffie, J. P., \& Pil, F. K. (2010). Employee voice and organizational performance: Team versus representative influence. Human Relations, 63(3), 371-394.

Lee, K., Ashton, M. C., Wiltshire, J., Bourdage, J. S., Visser, B. A., \& Gallucci, A. (2013). Sex, power, and money: Prediction from the Dark Triad and honesty-humility. European Journal of Personality, 27(2), 169-184.

Lilienfeld, S. O. (1994). Conceptual problems in the assessment of psychopathy. Clinical Psychology Review, 14(1), 17-38.

Lilienfeld, S. O., Latzman, R. D., Watts, A. L., Smith, S. F., \& Dutton, K. (2014). Correlates of psychopathic personality traits in everyday life: Results from a large community survey. Frontiers in Psychology, 5, 1-11.

Lilienfeld, S. O., Waldman, I. D., Landfield, K., Watts, A. L., Rubenzer, S., \& Faschingbauer, T. R. (2012). Fearless dominance and the US presidency: Implications of psychopathic personality traits for successful and unsuccessful political leadership. Journal of Personality and Social Psychology, 3, 489-505.

Lipman-Blumen, J. (2005). Toxic leadership: When grand illusions masquerade as noble visions. Leader to Leader, 36, 29-34.

Lynam, D. R., Caspi, A., Moffitt, T. E., Loeber, R., \& StouthamerLoeber, M. (2007). Longitudinal evidence that psychopathy scores in early adolescence predict adult psychopathy. Journal of Abnormal Psychology, 116(1), 155.

Marshall, A. J., Ashleigh, M. J., Baden, D., Ojiako, U., \& Guidi, M. G. (2015). Corporate psychopathy: Can "search and destroy "and "hearts and minds" military metaphors inspire HRM solutions? Journal of Business Ethics, 128, 495-504.

Mathieu, C., Neumann, C. S., Hare, R. D., \& Babiak, P. (2014). A dark side of leadership: Corporate psychopathy and its influence on employee well-being and job satisfaction. Personality and Individual Differences, 59, 83-88.

McCarthy, M. (1997). Remedies for the leaderless workforce: A review of the transformational leadership literature. International Journal of Employment Studies, 5(1), 117.

Mehta, S., \& Maheshwari, G. (2013). Consequence of toxic leadership on employee job satisfaction and organizational commitment. Journal of Contemporary Management Research, 8(2).

Miller, S. I., \& Fredericks, M. (1994). How does grounded theory explain. Qualitative Health Research, 9(4), 539.

Morris, J. A., Brotheridge, C. M., \& Urbanski, J. C. (2005). Bringing humility to leadership: Antecedents and consequences of leader humility. Human Relations, 58(10), 1323-1350.

Olster, S. (2012). Do psychopaths make good CEOs? Retrieved 19 Mar 2014 from http://features.blogs.fortune.cnn.com/2012/10/ 26/wisdom-psychopaths-dutton/.
Parzefall, M.-R., \& Salin, D. M. (2010). Perceptions of and reactions to workplace bullying: A social exchange perspective. Human Relations, 63(6), 761-780.

Raub, S., \& Robert, C. (2010). Differential effects of empowering leadership on in-role and extra-role employee behaviors: Exploring the role of psychological empowerment and power values. Human Relations, 63(11), 1743-1770.

Shao, P., Resick, C. J., \& Hargis, M. B. (2011). Helping and harming others in the workplace: The roles of personal values and abusive supervision. Human Relations, 64(8), 1051-1078.

Shin, Y. (2012). CEO ethical leadership, ethical climate, climate strength, and collective organizational citizenship behavior. Journal of Business Ethics, 108(3), 299-312.

Smith, S. F., \& Lilienfeld, S. O. (2013). Psychopathy in the workplace: The knowns and unknowns. Aggression and Violent Behavior, 18, 204-218.

Smith, S. F., Watts, A., \& Lilienfeld, S. (2014). On the trail of the elusive successful psychopath. The Psychologist, 27, 506-510.

Stake, R. E. (2000). Case studies. In N. K. Denzin \& Y. S. Lincoln (Eds.), Handbook of qualitative research (pp. 425-454). London: Sage.

Stein, M. (2003). Unbounded irrationality: Risk and organizational narcissism at long term capital management. Human Relations, $56(5), 523$.

Stevens, G., Deuling, J., \& Armenakis, A. (2012). Successful psychopaths: Are they unethical decision-makers and why? Journal of Business Ethics, 105, 139-149.

Stout, M. (2005). The ice people: Living among us are people with no conscience, no emotions and no conception of love: Welcome to the chilling world of the sociopath. Psychology Today, 38, 72-76.

Strom, S. (2009). Elie Wiesel levels scorn at Madoff. New York Times, p. 1 .

Tavanti, M. (2011). Managing toxic leaders: Dysfunctional patterns in organizational leadership and how to deal with them. Human Resource Management (HRM), 6, 127-136.

Taylor, A. J. W. (1964). An approach to the diagnosis and group treatment of criminal psychopathy. Human Relations, 17(3), 243-250.

Tepper, B. J. (2000). Consequences of abusive supervision. Academy of Management Journal, 43(2), 178-190.

Tepper, B. J. (2007). Abusive supervision in work organizations: Review, synthesis, and research agenda. Journal of Management, 33(3), 261-289.

Timothy, B., \& Gian, C. (2007). The relationship between leadership and follower in-role performance and satisfaction with the leader: The mediating effects of empowerment and trust in the leader. Leadership \& Organization Development Journal, 28(1), 4-19.

Treviño, L. K., Brown, M., \& Hartman, L. P. (2003). A qualitative investigation of perceived executive ethical leadership: Perceptions from inside and outside the executive suite. Human Relations, 56(1), 5.

Tsang, E. W. K. (2014). Generalizing from research findings: The merits of case studies. International Journal of Management Reviews, 16(4), 369-383.

Turnbull, S. (1997). Corporate governance: Its scope, concerns and theories. Corporate Governance: An International Review, 5(4), 180-205.

Turnley, W. H., \& Feldman, D. C. (1999). 'The impact of psychological contract violations on exit, voice, loyalty, and neglect. Human Relations, 52(7), 895-922.

Vickers, M. H. (2001). Bullying as unacknowledged organizational evil: A researcher's story. Employee Responsibilities and Rights Journal, 13(4), 205-217.

Vredenburgh, D., \& Brender, Y. (1998). The hierarchical abuse of power in work organizations. Journal of Business Ethics, 17(12), 1337-1347. 
Wayne, S. J., \& Green, S. A. (1993). The effects of leader-member exchange on employee citizenship and impression management behavior. Human Relations, 46(12), 1431-1440.

Weber, S., Habel, U., Amunts, K., \& Schneider, F. (2008). Structural brain abnormalities in psychopaths a review. Behavioral Sciences \& the Law, 26(1), 7-28.
Zona, F., Minoja, M., \& Coda, V. (2013). Antecedents of corporate scandals: CEOs' personal traits, Stakeholders' cohesion, managerial fraud, and imbalanced corporate strategy. Journal of Business Ethics, 113(2), 265-283. 